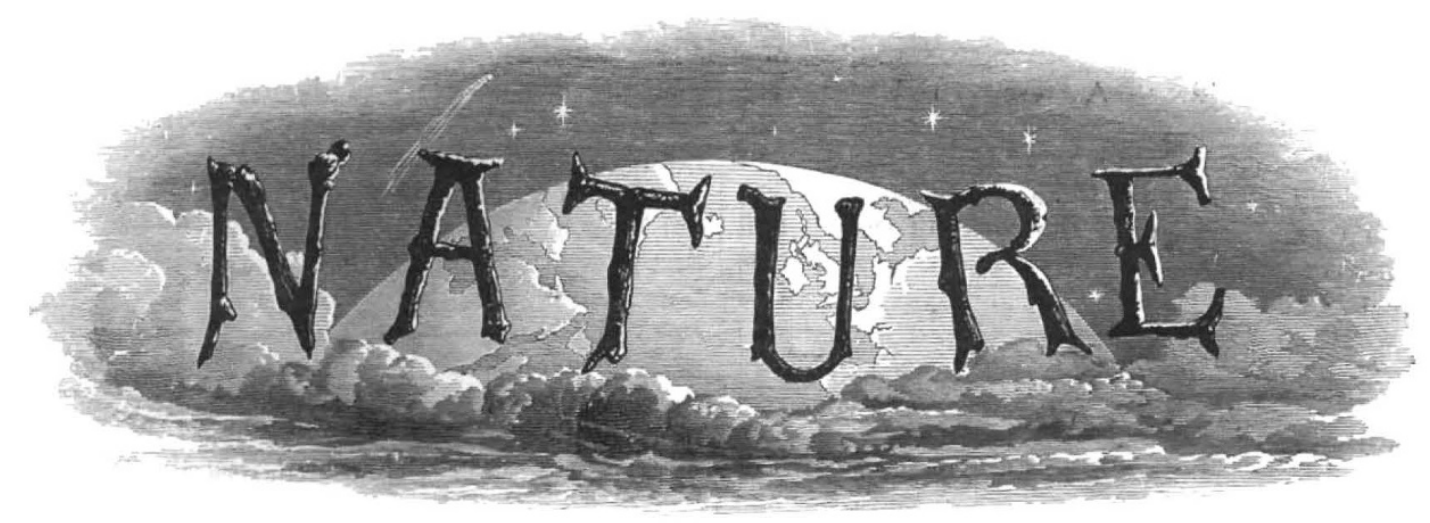

A WEEKLY ILLUSTRATED JOURNAL OF SCIENCE

\author{
"To the solial ground \\ of Nalure trusts the mind which builds for aye."-Wordsworm
}

THURSDAY, MAY 1, IS73

\section{THE WILD BIRDS PROTECTION ACT}

"CAVE me from my foolish friends," ought to be a stave in the spring-song of each fowl of the air, from the Nightingale which warbleth in darkness to the Dotterel which basketh at noonday. Last year, as is well known, a bill for the protection of "Vild Fowl" was brought into Parliament at the instance of the "Close-time" Committee of the British Association,* and the various changes and chances which befell it before it became an Act were succinctly recounted in the Committee's report at the Irighton meeting, printed in NATURE, vol. vi. p. 363 .

This bill, as at first prepared and introduced to the House of Commons, was framed entirely on the Sea-birds Preservation Act, which became law in 1869, and only differed from that successful measure where difference was needed, and the penalties and procedure it proposed were the same as those which have proved to be so thoroughly efficient in the former case. The minute care, the practical knowledge, and the consideration of various interests with which it was originally drawn, may be gathered from a few facts. Mlany of the birds it intended to protect are known in various parts of the country by various names, and accordingly all these names were introduced, for it was clear to the promoters of the bill, though not, as shown by the sequel, to the public at large, that a man summoned for killing (let us say) a Lapwing would never be convicted if he brought, as he easily might bring, credible witnesses who in good faith swore that it was a Peewit, and that they never heard it called anything else. At the same time, that the measure might not be needlessly severe, care was taken that of those species which bear different names in Scotland and England and do not breed in the latter, they should only appear under the name by which they This Committee in $58 \mathrm{II}-72$ consisted of Mr. Barnes, one of the secretaries of the Association for the Protection of Sea-birds, Mr. Dresser (reporter), Mr. Harting, Prof. Newton, and Canon Tristram, and it may be doubted whether five gentlemen more thoroughly conversant with the subSea-birds' Association, has since been added to their number.

No. $183-V o L$, VIII. are known in the former. A few species too, though coming strictly under the category of "Wild Fowl," were omitted because of their making themselves obnoxious to farmers. But the great feature of the bill was its being directed to a definite point-the preservation during the breeding season of those birds which, beyond all others, were and are subjected to cruel persecution at that time of year-thousands of Wild Ducks, Plovers, and Snipes, being constantly to be found in the poulterers' shops throughout the spring months, not only killed while they are breeding, but killed, it is not too much to say, because they are breeding, since during that season they put off much of their natural shyness and fall easy victims to the professional gunners. Furthermore, all who rcally know anything of birds know that it is just these kinds which are most rapidly diminishing in number-some of them, which in bygone days were most abundant, are now only seen as stray visitors. There is, for example, the Avocet, the disappearance of which can be plainly traced to its destruction by gunners, ${ }^{*}$ and had we space we could cite many similar cases. Then too, nearly all these birds are of no small importance as an article of food, and their supply to our markets has produced a trade of considerable extent.

Now, on the other hand, there are a good many enthusiastic persons, of whom we desire to speak with all respect, who have long been under the belief that in this country the number of birds generally, and of small birds in particular, has been gradually diminishing, and these persons wished for a much wider extension of the principle of protection than secmed to the "Close-time" Committee necessary or expedient. Whether their zeal is according to knowledge may be judged from what we have further to relate, but it is very plain that they disregard the widespread belief in the mischief popularly supposed to be caused by many of even our most useful small birds, and the fact, which no observer of experience can deny, that under certain circumstances, certain birds do a very considerable amount of harm-witness Song-thrushes and Blackbirds in the strawberry-beds-as well as that it is

"See Stevenson's "Birds of Norfolk," vol ii. p. 237 and following pages. 
only careful observation which will convince an unprejudiced man that the harm so done is outweighed by the general good. Further, tos, these persons overlook the impossibility of making people change their opinions by Act of Parliament, and it could be only when they become better acquainted with the great truths of natural history, that the desired results would follow. An attempt to force public opinion in this country generally fails.

Now this being the state of things when the "Wild Fowl Protection Bill" was introduced by Mr. Johnston, the enthusiasts at once tried to make it meet their ends. The history of the bill being, as we have said, accessible to our readers, there is no need for us to enter upon details, and we content ourselves by reminding them that, in an almost deserted House, Mr. Auberon Herbert, on the motion for going into committee, succeeded in carrying, by a majority of 20 to 15 , an "instruction" to extend the protection accorded under the bill to "Wild Fowl" to other wild birds, and thereupon the spirit of the Bill was entirely changed, and it was converted from the reasonable measure originally contemplated into one of indefinite and general scope. Persons of common sense at once saw that in its new shape it would be impracticable, not to say tyrannical, and notice was speedily given of its rejection. Its introduccr, however, contrived to get it referred to a Select Committec, by whom it was still further modified, the objections naturally urged against its sweeping clauses being overcome by limiting its effects to certain birds named in a schedule, while the penalties were diminished. The schedule, it is true, contained the names of all those birds originally included in the Bill, but miny others wcre added, though on what principle some were omitted and others introduced we cannot profess to say. No ornithologist whose opinion could carry the slightest weight appears to have been consulted, and it is needless to say that no ornithologist was among the twentythree members forming the Select Committee.*

Ve need not dwell further on historic details. It is now evident that the efforts of the enthusiasts-well intended as they doubtless were-have produced a law which is on all sides admitted to be virtually inoperative, instead of the effective measure which the results of the Sea-birds Act warrant us in believing that the original Bill would have proved. Substantial fines, which would have been resonable enough where professional gunners and poulterers were concerned, would have been manifestly cruel in the case of schoolboys. Accordingly the penalties were, to use the forcible expression we have heard applied, "sweated away" to suit the minor offenders, and the Act is almost a dead letter. Mr. Herbert, on the 2Ist of June last, laid a cuckoo's egg in the carefullybuilt ncst of the British Association Committee, and the produce is a useless monster - the wonder alike of the learned and the layman, and an awful warning as an example of amateur legislation. The forebodings of the "Close-Time" Committce have proved but too true. In its last Report we read-

"Your Committee cannot look with unmixed favour on this measure. It appears to them to attempt to do

* The printed "Proceedings" of the Select Committee do not throw much light on the subject The schedul : was proposed by Mr Samuelson Un a division the Onl was saved by 14 votes to 4 , the Hedge-Sparrow and Whinchat by the casting vote of the chairman, the Thrush was lost by 9 to 6 . All the birds added are included only under their book-names, which of course are, as every practical naturalist is aware, very different from those
by which they are commonly known. too much, and not to provide effectual means of doing it. In their former Reports thcy have hinted at, if not expressed, the difficulty or impossibility of passing any general measure, which, without being oppressive to any class of persons, should be adequate to the purpose. Further consideration has strengthened their opinion on this point. They fear the new Act, though far from a general measurc, will be a very inefficient check to the destruction of those birds, which, from their yearly decreasing numbers, most require protection, its restrain. ing power having been weakened for the sake of protecting a number of birds which do not require protection at all. Your Committee have néver succeeded in obtaining any satisfactory evidence, much less any convincing proof, that the numbers of small birds are generally decreasing in this country; on the contrary they believe that from various causes many, if not most, species of small birds are actually on the increase. They are therefore of opinion that an Act of Parliament proposing to promote their preservation is a piece of mistaken legislation, and is mischievous in its effect, since it diverts public attention from those species which, through neglect, indifference, custom, cupidity or prejudice, are suffering a persecution that will, in a few years, ensure their complete cxtermination."

We believe that this opinion is entirely correct, but our space would not allow us to adduce evidence in support of it. Mr. Herbert has now confessed the inutility of his handy-work, and some time since gave notice of a motion for the appointment of a Cummittee of the House of Commons to examine witnesses on the question. Before this article appears in print, our readers will know whether he gets what he wants. If he succeeds we suspect that not much good will follow. The eloquence of the enthusiasts is likely to overpower the reason of the true naturalists - a race not prone to sentimentality or given to sensationalism.

Ve would observe that the destruction of "Wild Fowl" stands on a very different footing from the destruction of "Small Birds," and if either is to be stopped it must be by different means. To check the first we believe no measure can be devised so complete as that which was last year spoilt by Mr. Herbert, but, since his unhappy success has taught Leadenhall Market that an Act of Parliament may be set at nought with impunity, it is quite possible that a new Act to be effectual should absolutely prohibit, within certain days, the possession or sale of the birds to be protected, irrespective of whether they can be proved to have been received from abroxd or not. The destruction of "small birds" is chiefly caused by professional bird-catchers, for the numbers killed by the gun is in most.cases comparatively trifling. The outcry that would be raised by farmers and marketgardeners, were they hindered from shooting the birds they find rifling their crops, would quickly repeal any Act which Parliament might inconsiderately pass to that effect. But we certainly should have no objection to putting the bird-catchers under some restriction, and we believe it would be to their own advantage if they were restrained from plying their art during the breedingseason. IVe shall no doubt be condemned by many excellent persons, but we cannot look upon bird-catchers as a class that should not be suffered to exist. The vocation of a bird-catcher may or may not conduce to the practice of all the virtues, but there is no reason for regarding it as essentially and necessarily vicious. Good and bad exist in every trade, bird-catching among the rest. We conceive that Mr. Sweedlepipes had a right to 
make his living-nay, to be protected in doing so as long as he did not exercise his calling to the detriment of the community. Of course this view will not suit the spasmodic writers of letters to the Times and other nowspapers with their passionate appeals on behalf of the harmless Hedge-Sparrow and the unappreciated Tomtit. Who is there that systematically persecutes either? Certainly not the bird-catcher even of the .blackest dye, begrimed with the soot of Seven Dials or Spitalfields. Are there not just as many Hedge-Sparrows and Tomtits in this country as there is room or food for? Are there not now many more Skylarlss and Chaffinches than there were before heaths were broken up and bogs drained, plantations made and "vermin" killed by the-gamekeepers? But our excellent enthusiasts cannot see this : with them are alike despicable and detestable the gardener who will not believe that the Bullinch is actuated by the purest and most benevolent motives in nipping off his apple-buds, and the farmor who doubts whether the Sparrow's ravages in his ripening grain are counterbalanced by that saucy bird's scrvices in the cabbagegarden. To them all birds are at all times bent on benefiting the human race. No statement in this direction is too gross for such people to swallow. The last we have met with is one of the most absurd. In the Quarterly Review for the present month (p. 402), we read that from some nameless moors the sportsman has been driven by the vipers, and the abundance of the vipers is owing to the extcrmination of "their natural enemy, the beautiful peregrine falcon"! Such a story is not worth refutation ; its original teller has said "that which is not," and the man who gravely repeats it is an idiot or worse.*

But now to conclude, we beg leave to offer the following suggestions :-

Ist. That the "IVild Fowl Protection Bill" be passed as originally introduced, with the possible exception of the sentence whereby fowls proved to have been imported from any foreign country are cxempted.

2nd. That a "Bill for the Regulation of Bird-catchers" be brought in-its chief feature being the absolute prohibition of bird-catching by means of traps, springes, or nets during the spring months-say from April I to July I, and that at other times of the year such engines should not be used within (say) 50 yards of any highway.

3rd. That the "sport" of Swallow-shooting be absolutely and at all times prohibited; and finally we may add that if a Chancellor of the Exchequer should ever take a hint from North Germany and lay a tax on birds in cages, we in the name of our Nightingales shall thank him.

\section{FAUNA DER KIELER BUCHT}

Fauna der Kieler Bucht. Zweiter Band : Prosobranchia und Lamellibranchia, nebst cinem supplement zu den Opisthobranchia. Mit 24 tafeln. Von H. A. Meyer und K. Möbius. Small folio, I39 pp. (Leipsic, 1872.)

WE are rejoiced to see the second volume of this excellent "ouvrage de luxe." Like the first volume, the second bears evident mar'zs of having been prepared

* It is painful, however, that such folly should be countenanced by reviews which in other respects are ceservediy of high repute. But in no department of criticism is there such a want of competent writers as in Zoology We are not exaggerating when we say that rine out of ten reviews of zoo.ogical works are written by men who have no sound knowledge of the olements
of the science. with the greatest care. The illustrations are inimitable and life-like: we venture to say that no such figures of Mollusca and their shells have ever been published in any country.

The introduction to the present volume contains an account of the currents, saline ingredients, and temperature of the water in Kiel Bay, together with elaborate tables of the latter properties in comparison with those in some other parts of the North Atlantic and in North Japan, as well as a notice of the peculiarities, distribution, and frequency of occurrence of the Kiel Bay Mollusca, and relative abundance of the genera and species in proportion to that of the Mollusca in Great Britain, Christianiafiord, and the Sound.

The body of the work embraces the subclass Prosobranchia (comprising the orders Cyclobranchiata, Pectinibranchiata, and Siphonobranchiata) of the class Gastropoda, a supplement to the first volume in respect of the other sub-class Opisthobranchiata (orders Pleurobranchiata and Pellibranchiata), and the Lamellibranchia (order Lamellibranchiata of the class Conchifera), with short diagnoses in Latin, and full descriptions in German of all the species given in the work. The admirable figures amply illustrate every character of the living animal and its shell, some being of the natural size, and others magnified 300 times.

We are not told whether any Brachiopod, marine Pulmonobranch, or Cephalopod inhabits Kiel Bay; but assuming the list to be complete, we find 23 species of Conchifera, and 40 of Gastropoda, being altogether $6_{3}$ species. There are 562 species of Mollusca in the British seas. This great difference may arise from the brackish nature of the water in Kiel Bay; and to the same cause may be attributable the small size of all the Mollusca, except Mytilus edulis, which is usually stunted on the open sea coast.

The authors have satisfactorily shown that the genus Triforis (erroneously changed by Deshayes to Triphoris) is distinct from Cerithium, although belonging to the same family, between which and Cerithiopsidce it appears to be intermediate. The principal difference consists in the animal of Triforis having a retractile proboscis; and Lovén's description of $T$. perversa was doubtful on that point. Other writers on the Mollusca have done nothing to help us in the classification of this difficult group. The shells are distinguishable by the shape of the mouth, which is very peculiar in Triforis; and the sculpture of the apex differs from that of Cerithinm-an important character which might have been advantageously represented in the plate before us.

We hope the authors will not take amiss a few slight criticisms. Their Rissoa inconspicuta is not Alder's species, but $R$. albella of Lovén. R. octona of Linné is probably a variety of Hydrobia ulvee, judging from his description and the habitat "in Svecia subpaludosis." The species described and figured by Meyer and Möbius as $R$. octona has two more (viz. ten) whorls; it is not horn-colour, but variegated; the mouth is oval, and not "fere orbiculata ;" and Linné does not mention the ribs which characterise the Kiel Bay species. The figures of Rissoa striata do not show the foot-appendage or caudal cirrus, although it is described in the work. Amphisphyra should be Utriculus. 